\title{
Th2 cells as an intermediate for the differentiation of naïve $T$ cells into Th9 cells, associated with the Smad3/Smad4 and IRF4 pathway
}

\author{
MOHAMED HAMED ABDELAZIZ ${ }^{*}$, HUIXUAN WANG ${ }^{1 *}$, JIANJUN CHENG $^{1,2}$ and HUAXI XU ${ }^{1}$ \\ ${ }^{1}$ Department of Immunology, School of Medicine, Jiangsu University, Zhenjiang, Jiangsu 212013; \\ ${ }^{2}$ Department of Laboratory Medicine, The Affiliated Hospital of Jiangsu University, Zhenjiang, Jiangsu 212001, P.R. China
}

Received November 10, 2018; Accepted June 26, 2019

DOI: $10.3892 /$ etm.2020.8420

\begin{abstract}
Type 9 T-helper (Th9) cells are associated with atopic and inflammatory diseases. Their increased levels and functions contribute to a number of inflammatory disorders, where they are accompanied by enhanced Th2-cell activity. However, there is currently no consensus regarding the association between Th9 and Th 2 cells. Th9 cells may be induced from naïve $\mathrm{T}$ (Th0) cells under specific polarization conditions in vitro, a process driven by the addition of specific cytokines. In the present study, Th0 cells were cultured under Th9-polarizing conditions to promote differentiation into interleukin (IL)-4+ IL-9- $^{-}$or IL-4- IL- $^{+}$T cells after 3 or 5 days in culture, respectively; the mRNA expression levels of IL-9 and IL-4 were consistent with the induced cell types. Simultaneously, the levels of interferon-regulatory factor 4 (IRF-4) and Smad3/Smad4 were significantly increased following Th9-cell polarization. It was therefore proposed that Th 2 cells may be generated in the early stages of Th9-cell differentiation, and then ultimately differentiate into Th9 cells via the Smad3/Smad4 and IRF-4 activation pathway.
\end{abstract}

\section{Introduction}

Following the activation of CD3 and CD28, the primary and secondary signals for T-cell differentiation, respectively, naïve $\mathrm{T}(\mathrm{Th} 0)$ cells have the ability to develop into different $\mathrm{T}$ helper (Th) cell subsets. The recognition of other Th-cell subsets, including type-17 Th cells (Th17) (1-3), T-regulatory (Treg), Th9 and Th22 cells, particularly with regard to the plasticity of these cells, gradually shifted the research priority from that of

Correspondence to: Dr Huaxi Xu, Department of Immunology, School of Medicine, Jiangsu University, 301 Xuefu Road, Zhenjiang, Jiangsu 212013, P.R. China

E-mail:xuhx@ujs.edu.cn

*Contributed equally

Key words: Th9 cells, Th2 cells, Smad3, interferon-regulatory factor 4 the ratio of Th1 and Th2 cells to that of the mutual association between various $\mathrm{CD}^{+}{ }^{+} \mathrm{T}$-cell subsets.

Th9 cells, a more recently described subset of effector Th cells, have promoted the general understanding of T-cell functioning. Interleukin (IL)-9, the primary cytokine produced by Th9 cells, is a type- 2 pleiotropic cytokine that not only regulates autoimmune and allergic reactions, but is involved in anti-parasitic and anti-tumor responses, and the formation of immune tolerance (4-6). However, the differentiation, development and immunological characteristics of Th9 cells have remained largely elusive. Previous studies have indicated that Th2 cells were able to differentiate into Th9 cells following the addition of transforming growth factor $\beta$ (TGF- $\beta$ ) in the presence of IL-4 (7), and that Th9 cell polarization was further enhanced by IL-1, IL-2 and IL-25 (8-10).

TGF- $\beta$ signaling is mediated through its binding to type I and type II receptors, and the activated ligand-receptor complex typically activates Smad-dependent signal transduction (11). The canonical Smad signaling cascade is initiated by the phosphorylation of Smad2 and/or Smad3. This allows Smad2 and/or Smad3 to bind to Smad4 with subsequent nuclear translocation of the complex and the recruitment of transcriptional co-activators or co-repressors to Smad-binding elements in the promoters of TGF- $\beta$ target genes (12).

The present study revealed that Th2 cells may be an indispensable intermediate during the differentiation of $\mathrm{Th} 0$ cells into Th9 cells, which depends on the activation of the Smad3/Smad4 and interferon-regulatory factor 4 (IRF-4) pathways.

\section{Materials and methods}

Animals. A total of 20 Female Balb/c mice (weight, 18-22g; age, 6-8-weeks) were purchased from the Comparative Medicine Centre of Yangzhou University (Yangzhou, China) and housed in a pathogen-free facility at Jiangsu University (Zhenjiang, China). All procedures were approved and supervised by the Animal Ethical Committee of Jiangsu University (Zhenjiang, China).

In vitro T-cell differentiation and flow cytometric analysis. Th0 cells were prepared from the spleens of 6-8 week-old 
female Balb/c mice under sterile conditions. The isolation process was performed according to the manufacturer's protocol (Miltenyi Biotec, Inc.). CD4 ${ }^{+} \mathrm{Th} 0$ cells were activated with plate-bound anti-CD3 (eBiosciences; cat. no. 16-0031-85; Thermo Fisher Scientific, Inc.) and anti-CD28 (eBiosciences; cat. no. 16-0281-82; Thermo Fisher Scientific, Inc.) antibodies, and supplemented with recombinant mouse IL-4 and TGF- $\beta$ (Peprotech, Inc.). After 3 or 5 days, the cultured cells were stimulated using phorbol 12-myristate 13-acetate (50 ng/ml; Sigma-Aldrich; Merck KGaA) and ionomycin (1 $\mu \mathrm{g} / \mathrm{ml}$; Sigma-Aldrich; Merck KGaA) in the presence of monensin ( $2 \mathrm{~g} / \mathrm{ml}$; Sigma-Aldrich; Merck KGaA) for $4 \mathrm{~h}$ at $37^{\circ} \mathrm{C}$ in an atmosphere containing $5 \% \mathrm{CO}_{2}$. The cells were then fixed and permeabilized using permeabilization buffer (Invitrogen; Thermo Fisher Scientific, Inc.) for intracellular staining, the phycoerythrin-conjugated anti-mouse IL-9 and Per-cy5.5-conjugated anti-mouse IL-4 antibodies (1:200; cat. no. 130-102-442; Peprotech, Inc.) co-cultured with the cells at $4^{\circ} \mathrm{C}$ for $30 \mathrm{~min}$ according to the manufacturer's protocol. The labeled cells were analyzed using an Accuri C6 flow cytometer with CFlow Sampler software (GraphPad Prism 5; BD Biosciences). The $\mathrm{CD}^{+}{ }^{+} \mathrm{IL}^{+}{ }^{+} \mathrm{IL}^{-}{ }^{-}$cell population was considered to be Th2 cells and the CD4+ IL 4 - IL $9^{+}$cell population was regarded as Th9 cells.

Reverse transcription-quantitative (RT-q)PCR analysis. Following culture for 3 and 5 days under Th9-polarization conditions, total RNA was extracted from T cells using the guanidinium thiocyanate phenol chloroform method, and the total RNA was used to generate complementary DNA with the PrimeScript RT Reagent Kit (Takara Bio, Inc.) according to the manufacturer's protocol. The primers were designed using Premier 5.0 software on the basis of GenBank sequences and synthesized by Sangon Biotech Co., Ltd. The sequences of all primers used are presented in Table I. qPCR was performed using SYBR Premix ExTaq (Takara Bio, Inc.) according to the manufacturer's protocol. Pre-denaturation was performed at $95^{\circ} \mathrm{C}$ for $5 \mathrm{~min}$, denaturation was performed at $95^{\circ} \mathrm{C}$ for $30 \mathrm{sec}$, annealing was performed at $72^{\circ} \mathrm{C}$ for $30 \mathrm{sec}$ and extension was performed at $65^{\circ} \mathrm{C}$ for $1 \mathrm{~min}$. Fold changes in the expression of each gene relative to $\beta$-actin were calculated using the comparative threshold cycle $(\mathrm{Ct})$ method (13). All experiments were performed in triplicate.

Statistical analysis. Values are expressed as the mean \pm standard deviation. GraphPad Prism Version 5.0 (GraphPad Software, Inc.) was used to perform statistical analysis of the data. The unpaired Student's t-test or Mann Whitney U-test (for RT-qPCR data) was applied according to the results of homogeneity of variance testing. In addition, analysis of variance and Tukey's multiple-comparisons test were used for statistical analysis of the flow cytometric data. $\mathrm{P}<0.05$ was considered to indicate a statistically significant difference.

\section{Results}

Variations in Th2 cell number during the induction of Th9 cells using TGF- $\beta$ and $I L-4$. At the optimum concentration of TGF- $\beta(5 \mathrm{ng} / \mathrm{ml})$, the number of induced Th9 cells in vitro was
Table I. Primer sequences for PCR.

\begin{tabular}{|c|c|c|}
\hline Gene & Primer sequence $\left(5^{\prime}-3^{\prime}\right)$ & $\begin{array}{c}\text { Product } \\
\text { length } \\
\text { (bp) }\end{array}$ \\
\hline$\beta$-actin & $\begin{array}{l}\text { F: ATGGAAATGGGGAAGATGGTC } \\
\text { R: GCGGGGAGGGTGTGAACT }\end{array}$ & 349 \\
\hline IL-4 & $\begin{array}{l}\text { F: GGTCTCAACCCCCAGCTAGT } \\
\text { R: GCCGATGATCTCTCTCAAGTGAT }\end{array}$ & 102 \\
\hline IL-9 & $\begin{array}{l}\text { F: GGGCATCAGAGACACCAATTA } \\
\text { R: AACAGTCCCTCCCTGTACTCAC }\end{array}$ & 119 \\
\hline PU.1 & $\begin{array}{l}\text { F: CCCTCCATCGGATGACTTGGTT } \\
\text { R: GTTGTTGTGGACATGGTGTGCG }\end{array}$ & 142 \\
\hline IRF-4 & $\begin{array}{l}\text { F: GGTGTGGGAGAACGAGGAGAAG } \\
\text { R: TCCTCTCGACCAATTCCTCAAA }\end{array}$ & 221 \\
\hline GATA-3 & $\begin{array}{l}\text { F: ACCACGGGAGCCAGGTATG } \\
\text { R: CGGAGGGTAAACGGACAGAG }\end{array}$ & 170 \\
\hline Smad2 & $\begin{array}{l}\text { F: GCAGAATATCGGAGGCAGACA } \\
\text { R: GATGGGTTTACGACATGCTTGA }\end{array}$ & 142 \\
\hline Smad3 & $\begin{array}{l}\text { F: GGAGCAGAGTACAGGAGACA } \\
\text { R: AACCCGCTCCCTTTACTCCTA }\end{array}$ & 165 \\
\hline Smad4 & $\begin{array}{l}\text { F: GCTCCAGCCATCAGTCTGTC } \\
\text { R: TGGTGTGCAGGACTTCATCC }\end{array}$ & 193 \\
\hline
\end{tabular}

IL, interleukin; IRF-4, interferon-regulatory factor 4; GATA-3, GATA binding protein $3 ; \mathrm{F}$, forward; $\mathrm{R}$, reverse.

markedly enhanced with increasing concentrations of IL-4. As the basic prerequisite for the generation of Th9 cells ex vivo, IL-4 and TGF- $\beta$ were used at different concentrations to induce Th9-cell differentiation in vitro. The results suggested that the optimum cytokine concentrations required to induce the differentiation of Th0 to Th9 cells were $30 \mathrm{ng} / \mathrm{ml} \mathrm{IL-4}$ and $5 \mathrm{ng} / \mathrm{ml} \mathrm{TGF}-\beta$, and that the number of Th9 cells peaked following 5 days of induction under these conditions (Fig. 1). It was also revealed that Th2 cells were generated from Th0 cells at the 3-day time-point, which then differentiated into Th9 cells at day 5 when treated with appropriate concentrations of TGF- $\beta$ and IL-4 (Fig. 2).

Variations in the expression levels of Th9-and Th2-associated cytokines and transcription factors during the generation of Th9 cells. IL-4 and IL-9 may be considered as the signature cytokines produced by Th2 and Th 9 cells, respectively. Cell differentiation may cause alterations in the expression levels of associated cytokines and transcription factors. In the present study, the expression levels of IL-4 or IL-9 mRNA were evaluated; the results indicated that expression levels were consistent with the cell subsets cultured for 3 or 5 days, respectively, and that the expression levels of IL-4 and IL-9 were significantly different between these two time-points (day 3 and 5; Fig. 3A and B). Simultaneously, the mRNA expression levels of Th9-associated transcription factors PU.1 (Sfpi1), GATA protein 3 (GATA-3) and IRF-4 were analyzed and the data indicated that the expression of PU.1 was significantly 

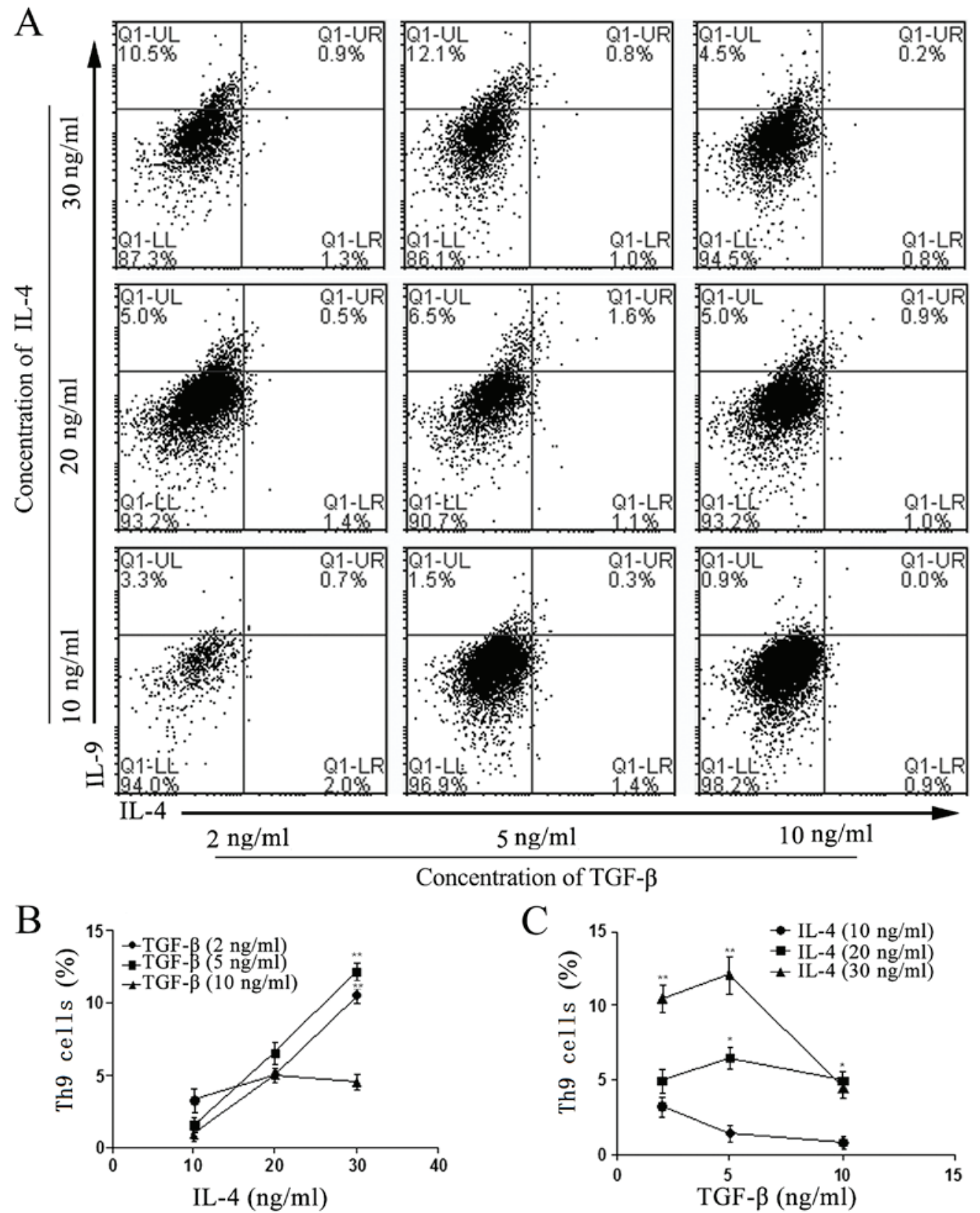

Concentration of TGF- $\beta$

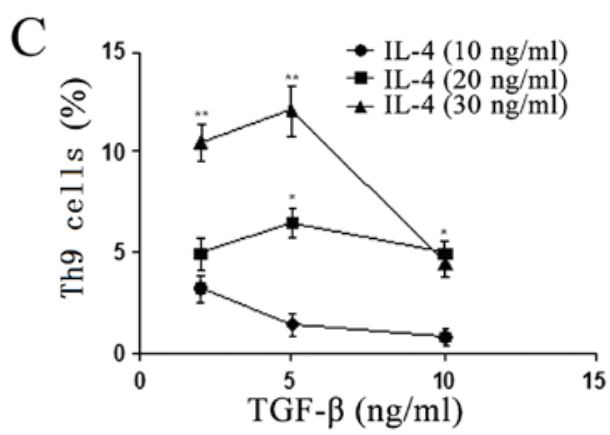

Figure 1. Effects of IL-4 and TGF- $\beta$ on the differentiation of naïve T cells into Th9 cells. (A) Flow cytometric analysis of the differentiation rate of Th9 cells (IL-4- IL-9+), developed from naïve T cells isolated from the spleens of Balb/c mice. Isolation was performed using magnetic beads cultured with 2, 5 or $10 \mathrm{ng} / \mathrm{ml}$ TGF- $\beta$, and 10, 20 or $30 \mathrm{ng} / \mathrm{ml} \mathrm{IL-4}$ at day 5 . (B) Effects of 10,20 and $30 \mathrm{ng} / \mathrm{ml} \mathrm{IL-4} \mathrm{on} \mathrm{the} \mathrm{differentiation} \mathrm{into} \mathrm{Th9} \mathrm{cells} \mathrm{at} 2,5 \mathrm{and} 10 \mathrm{ng} / \mathrm{ml}$ TGF- $\beta$. ${ }^{* *} \mathrm{P}<0.01 \mathrm{vs} .10 \mathrm{ng} / \mathrm{ml}$ TGF- $\beta$. (C) Effects of TGF- $\beta$ (2, 5 and $\left.10 \mathrm{ng} / \mathrm{ml}\right)$ on the differentiation of Th9 cells with 10, 20 and $30 \mathrm{ng} / \mathrm{ml} \mathrm{IL-4.} \mathrm{P}<0.05 \mathrm{and}{ }^{* * *} \mathrm{P}<0.01$ vs. $10 \mathrm{ng} / \mathrm{ml} \mathrm{IL}-4$. Values are expressed as the mean \pm standard deviation of triplicate experiments. IL, interleukin; TGF- $\beta$, transforming growth factor $\beta$; Th9 cell, type 9 T-helper cell; Q, quadrant; UL, upper left; LR, lower right.

decreased, while that of IRF-4 was markedly elevated after 5 days of incubation; no obvious change was observed in the expression level of GATA-3 mRNA (Fig. 3C-E).

Increased expression of Smad3/Smad4 is associated with the differentiation of Th2 to Th9 cells. TGF- $\beta$ is pivotal in the induction of Th9 cells in vivo and in vitro (9-11). As significant components of the TGF- $\beta$ signaling pathway, the mRNA expression levels of Smad2, -3 and -4 were determined. The results revealed that the expression levels of Smad3 and Smad4 on the 5th day were significantly enhanced following IL- 4 and TGF- $\beta$ supplementation, but no significant difference was identified in the expression level of Smad2 (Fig. 4).

\section{Discussion}

Originally, Th9 cells were characterized by the secretion of IL-9, and as such, were identified as an independent Th-cell subset $(7,14)$. As the production of IL-9 was detected in Th9, not Th2 cells, the initial emphasis of research on IL-9-producing Th2 cells was redirected to the occurrence and development of cells (15). Previous observations have revealed that the addition of TGF- $\beta$, a cytokine with wide-ranging actions in the immune system, may alter the characteristics of Th2 cells; this may include the loss of GATA-3 expression and the Th2-associated cytokines IL-4, IL-5 and IL-13, resulting in the production IL-9. However, the identification of IL-9-producing T cells 
A

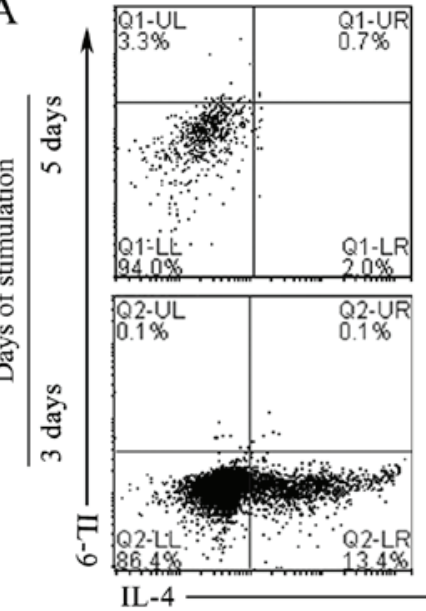

IL-4 (ng/ml) $\quad 10$

TGF- $\beta(\mathrm{ng} / \mathrm{ml}) \quad 2$

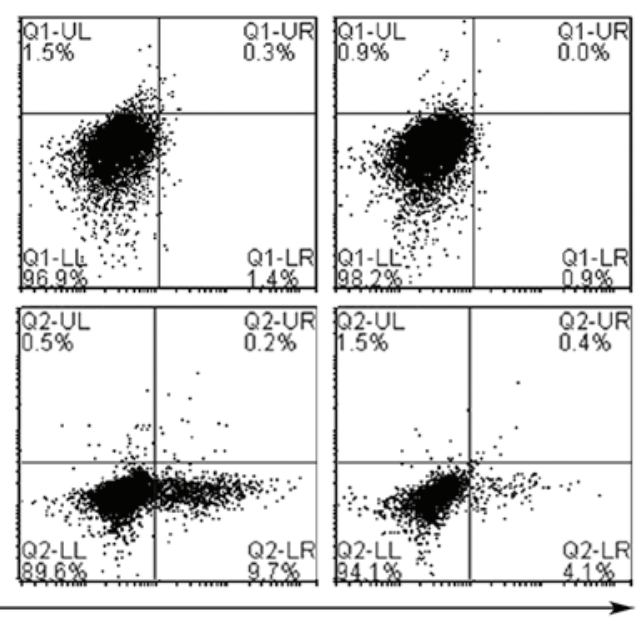

10
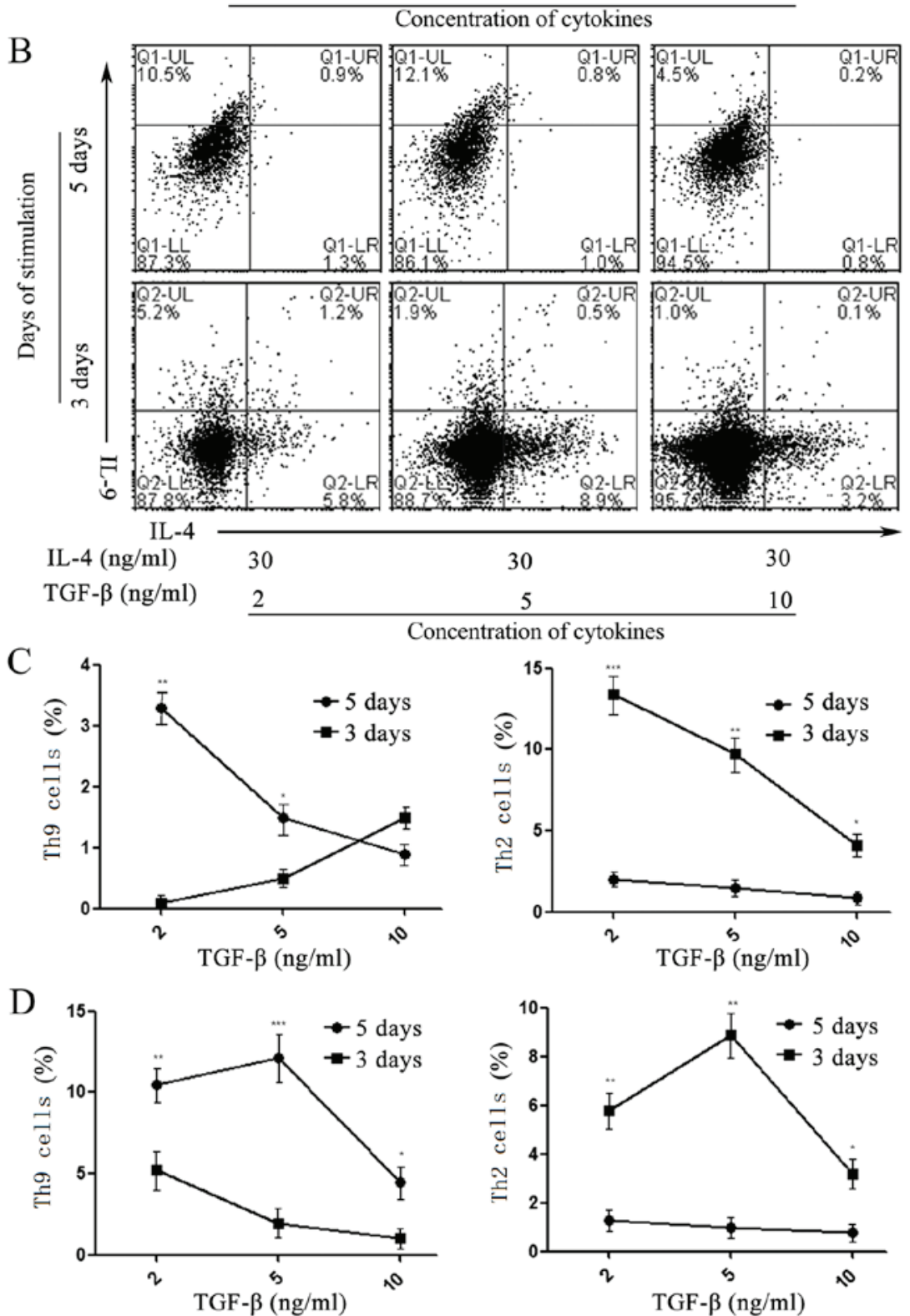

Figure 2. Effects of induction time on the differentiation of Th9 cells activated by IL-4 and TGF- $\beta$. Flow cytometry indicated the differentiation rate of Th9 (IL-4- IL-9+) or Th2 (IL-4+ IL-9-) cells developed from Naïve T cells isolated using magnetic beads, and treated with $2,5 \mathrm{and} 10 \mathrm{ng} / \mathrm{ml}$ TGF- $\beta$ in the presence of (A) 10 or (B) $30 \mathrm{ng} / \mathrm{ml} \mathrm{IL-4}$ at days 3 and 5, respectively. The effect of induction time on the differentiation of Th9 and Th2 cells stimulated with 2,5 and $10 \mathrm{ng} / \mathrm{ml}$ TGF- $\beta$ in the presence of (C) 10 and (D) $30 \mathrm{ng} / \mathrm{ml} \mathrm{IL-4}$ at days 3 and 5. Values are expressed as the mean \pm standard deviation of triplicate experiments. "P<0.05, ${ }^{* *} \mathrm{P}<0.01,{ }^{* * *} \mathrm{P}<0.001$. IL, interleukin; TGF- $\beta$, transforming growth factor $\beta$; Th9 cell, type 9 T-helper cell; Q, quadrant; UL, upper left; LR, lower right. 

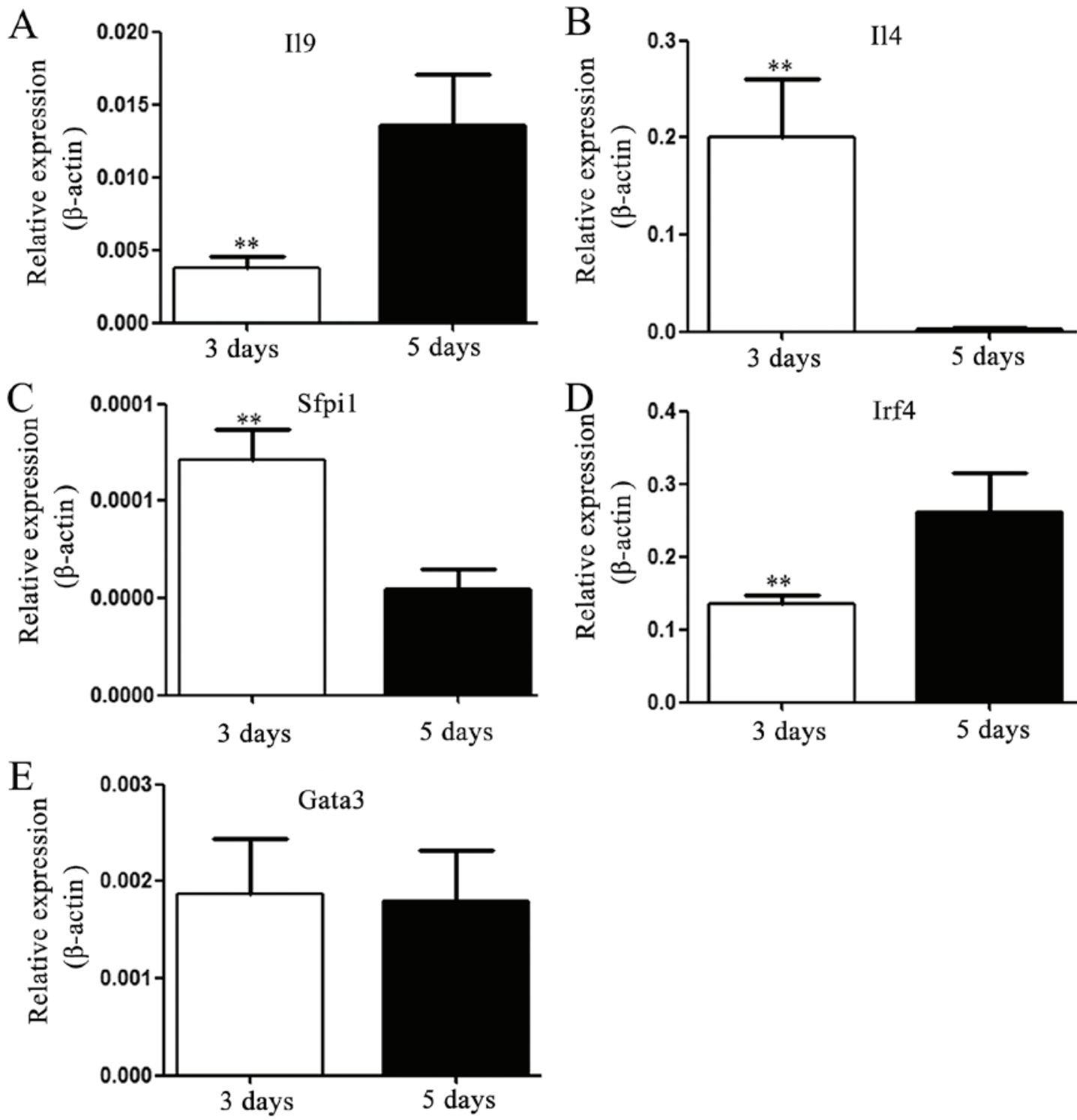

Figure 3. Expression levels of Th9-associated cytokines and transcription factors. After culture for 3 or 5 days, the expression levels of IL-4, IL-9, PU.1, IRF-4 and GATA-3 mRNA extracted from inducible naïve T cells, activated with $30 \mathrm{ng} / \mathrm{ml} \mathrm{IL-4}$ and $5 \mathrm{ng} / \mathrm{ml}$ TGF- $\beta$ were detected using reverse transcription-quantitative PCR. Th9-associated cytokines: (A) IL-9 and (B) IL-4; transcription factors: (C) PU.1, (D) Irf4 and (E) GATA-3. Values are expressed as the mean \pm standard deviation of triplicate experiments. "** P<0.01 vs. day 5. IL, interleukin; TGF- $\beta$, transforming growth factor $\beta$; Th9 cell, type 9 T-helper cell; IRF-4, interferon-regulatory factor 4; GATA-3, GATA binding protein 3.

as novel members of the ever-expanding $\mathrm{CD} 4^{+} \mathrm{T}$-cell family, has resulted in a nomenclature issue due to the lack of unique expression profiles for T-bet, GATA-3, RAR-related orphan receptor $\gamma t$ or forkhead box P3, which are known subset-determining transcription factors associated with Th1, Th2, Th17 and Treg cells, respectively. Among these transcription factors, PU.1, IRF-4 and GATA-3 are notably associated with the differentiation of Th2 cells (16-19). Therefore, it is conceivable that the change in identification from IL-9-producing Th2 to Th9 cells is not as simple as a change in cytokine profiles, and that the defining mechanistic differences between these cells require further elucidation.

Early studies of Th9 cells focused primarily on the regulatory factors associated with IL-9 transcription, and their influences on immune-associated diseases. A great deal of attention has been paid to the involvement of IL- 4 and TGF- $\beta$ in the transcription of the IL-9 gene in Th2 type-associated immune disease models, including allergic airway disease (AAD) and experimental autoimmune encephalomyelitis. The role of Th9 cells in inflammation was documented in a $\mathrm{Rag}^{-/}$mouse AAD model via the adoptive transfer of these cells (17). Furthermore, PU.1 was revealed to attenuate the expression of IL-9 in mice with a PU.1 defect (16). This suggests that PU.1 is a primary transcription factor associated with Th9-induced inflammation. Concurrently, PU.1 is also associated with the expression of IL-4 in various other cell types, including in the survival of B cells. Simultaneously, Staudt et al (18) indicated that IRF-4 (a principal participant in Th2-cell development) is also crucial to the differentiation and function of Th9 cells. Previous studies have also determined that a number of other cytokines influence the generation of Th2 cells, including IL-2, IL-25, IFN- $\gamma$ IL-21 and IL-27, and that they may serve similar roles in the generation of Th9 cells (20-23). 

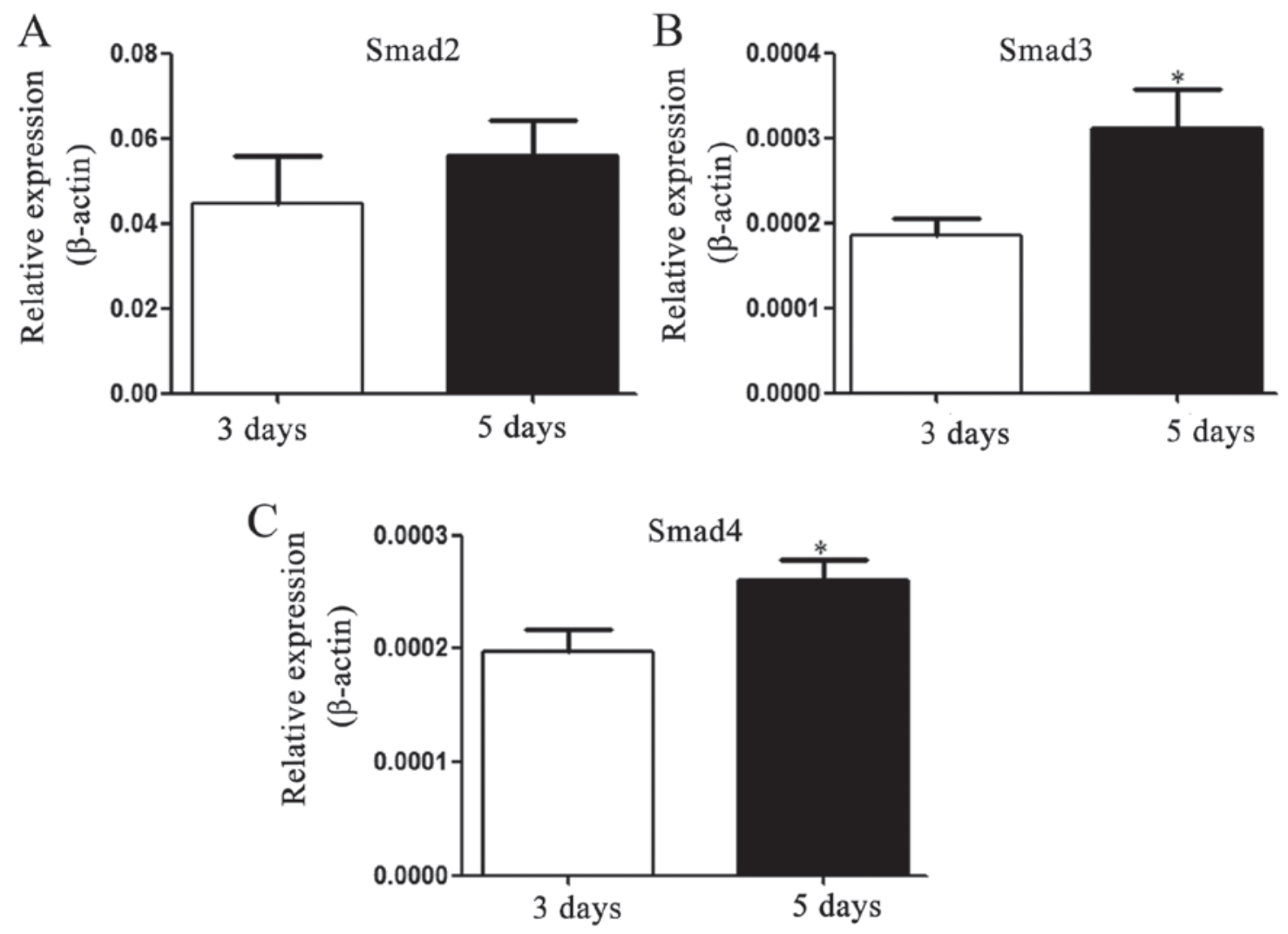

Figure 4. Expressions levels of Smad2, -3 and -4 mRNA. Following culture for 3 or 5 days, Smad2, -3 and -4 mRNA extracted from inducible naïve T cells activated using $30 \mathrm{ng} / \mathrm{ml} \mathrm{IL}-4$ and $5 \mathrm{ng} / \mathrm{ml}$ TGF- $\beta$ was detected using reverse transcription-quantitative PCR. TGF- $\beta$-Smad pathway-associated signaling molecules: (A) Smad2, (B) Smad3 and (C) Smad4. Values are expressed as the mean \pm standard deviation of triplicate experiments. "P<0.05 vs. 3 days. IL, interleukin; TGF- $\beta$, transforming growth factor $\beta$; Th9 cell, type 9 T-helper cell.

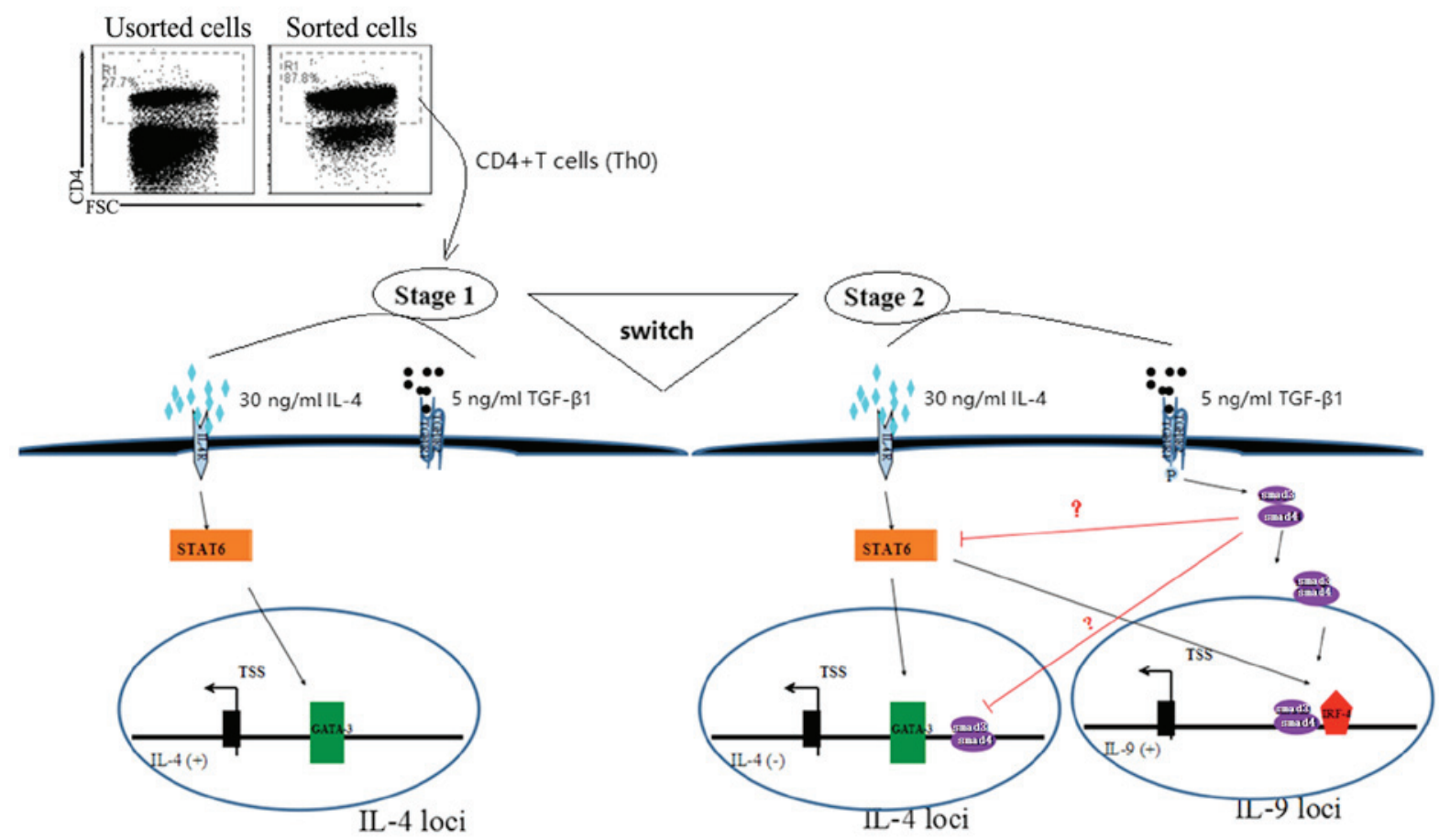

Figure 5. Differentiation of Th2 to Th9 cells using TGF- $\beta$ and IL-4. The transformation process of Th2 to Th9 cells from Th0, in the presence of $5 \mathrm{ng} / \mathrm{ml}$ TGF- $\beta$ and $30 \mathrm{ng} / \mathrm{ml} \mathrm{IL-4,} \mathrm{in} \mathrm{which} \mathrm{the} \mathrm{Th0} \mathrm{cells} \mathrm{underwent} \mathrm{two} \mathrm{developmental} \mathrm{stages.} \mathrm{In} \mathrm{the} \mathrm{first} \mathrm{stage,} \mathrm{the} \mathrm{Th2-specific} \mathrm{transcription} \mathrm{factor} \mathrm{GATA3} \mathrm{was}$ activated by IL-4 via the STAT6 pathway, resulted in the autocrine activation of IL-4, leading to the appearance of Th2 characteristics. In the second stage, with the prolongation of TGF- $\beta$ stimulation time, Smad3 and/or Smad4 were activated, which further activated the transcription factor IRF-4 and may have inhibited GATA3 activity, leading to the conversion of cytokines secreted by cells from IL-4 to IL-9, and the emergence of Th9-cell characteristics. Th9 cell, type 9 T-helper cell; TGF- $\beta$, transforming growth factor $\beta$; IL, interleukin; IRF-4, interferon-regulatory factor 4; GATA-3, GATA binding protein 3; FSC, forward scatter, is positively correlated with the square of cell diameter (cell size). 
It is commonly understood that the development of different $\mathrm{Th}$ subtypes relies on the appropriate external signals. Similar to the conditions required to promote Th1-, Th2-, Th17- and Treg-cell differentiation, Th9 cells are generated from Th0 cells in response to TGF- $\beta$ and IL-4, in addition to other cytokines in the extracellular milieu (24). The current consensus is that the differentiation period for Th subsets activated using anti-CD3/CD28 differs from that of physiological activation using specific antigen (25). It is noted that TGF- $\beta$, as an immune-regulatory cytokine, not only regulates the differentiation of Th-cell subsets, but is also involved in apoptosis and cell survival (26-28). Takami et al (29) demonstrated that in the presence of IL- 4 , TGF- $\beta$ was able to convert p53-induced CD28-dependent apoptosis-associated stimuli into the signal for Th9 differentiation. Therefore, TGF- $\beta$ has been studied as a key molecule involved in the generation of Th9 cells in vitro (30).

It has been demonstrated that TGF- $\beta$ redirects the differentiation of Th0 cells from Th2 to Th9 cells (7). In light of this, the induction rates of $\mathrm{Th} 2$ and $\mathrm{Th} 9$ cells in response to optimum Th9-cell polarization conditions were analyzed at different time-points ex vivo. Furthermore, changes in the expression levels of IL-4, IL-9, GATA-3, Pu.1, IRF-4, Smad2, Smad3 and Smad4 were measured. The results of the present study illustrated that differentiation into Th2 cells was a necessary process for the induction of Th9 cells in Th9-polarizing culture conditions, and that Th2 cells may be an intermediate in the conversion of Th0 into Th9 cells in the presence of TGF- $\beta$ and IL-4 (Fig. 5). In other words, Th9 cells were not directly generated from Th0 cells, and may represent a stable state following the intermediate generation of Th2 cells. The present study also suggested that although PU.1, IRF-4 and GATA-3 were expressed by Th2 and Th9 cells, the expression of IRF-4 was significantly upregulated, while PU.1 mRNA expression was downregulated in Th9 cells. In addition, the decrease in PU.1 expression levels was associated with the downregulation of IL-4 expression. It was speculated that Th2 cells may be generated in the early stage of Th9-cell differentiation, which are then converted to Th9 cells via the Smad3/Smad4 and IRF-4 activation pathways. However, the complete mechanism of Th9-cell generation remains elusive, and further investigation is required to identify novel prophylactics and treatments for Th9-associated pathologies.

\section{Acknowledgements}

The authors would like to thank Mr Qiaolin Chen (Institute of Laboratory Medicine, Jiangsu University) and Professor Zhijun Jiao (Affiliated Hospital of Jiangsu University) for technical assistance.

\section{Funding}

The present study was supported by grants from the National Natural Science Foundation of China (grant no. 81771756), the Key University Science Research Project of Jiangsu Province (grant no. 16KJA320005), the Social Development Project of Jiangsu Province (grant no. BE2016716) and the Postdoctoral Foundation of Jiangsu Province (grant no. 1601002C).

\section{Availability of data and materials}

The materials used during the present study are available from the corresponding author on reasonable request.

\section{Authors' contributions}

MHA and HX conceived and designed the present study. MHA, HW and JC performed the experiments and analyzed the data. All the authors have read and approved the final manuscript.

\section{Ethics approval and consent to participate}

All animal procedures were approved and supervised by the Animal Ethical Committee of Jiangsu University (Zhenjiang, China).

\section{Patient consent for publication}

Not applicable.

\section{Competing interests}

The authors declare that they have no competing interests.

\section{References}

1. Zhou L, Chong MM and Littman DR: Plasticity of CD4(+) T cell lineage differentiation. Immunity 30: 646-655, 2009.

2. Tan C, Aziz MK, Lovaas JD, Vistica BP, Shi G, Wawrousek EF and Gery I: Antigen-specific Th9 cells exhibit uniqueness in their kinetics of cytokine production and short retention at the inflammatory site. J Immunol 185: 6795-6801, 2010.

3. Shi G, Cox CA, Vistica BP, Tan C, Wawrousek EF and Gery I: Phenotype switching by inflammation-inducing polarized Th17 cells, but Not by Th1 cells. J Immunol 181: 7205-7213, 2008.

4. Kabata H, Moro K and Koyasu S: The group 2 innate lymphoid cell (ILC2) regulatory network and its underlying mechanisms. Immunol Rev 286: 37-52, 2018.

5. Noelle RJ and Nowak EC: Cellular sources and immune functions of interleukin-9. Nat Rev Immunol 10: 683-687, 2010.

6. Purwar R, Schlapbach C, Xiao S, Kang HS, Elyaman W, Jiang X, Jetten AM, Khoury SJ, Fuhlbrigge RC, Kuchroo VK, et al: Robust tumor immunity to melanoma mediated by interleukin-9-producing T cells. Nat Med 18: 1248-1253, 2012

7. Veldhoen M, Uyttenhove C, van Snick J, Helmby $H$, Westendorf A, Buer J, Martin B, Wilhelm C and Stockinger B: Transforming growth factor-beta 'reprograms' the differentiation of T helper 2 cells and promotes an interleukin 9-producing subset. Nat Immunol 9: 1341-1346, 2008.

8. Schmitt E, Germann T, Goedert S, Hoehn P, Huels C, Koelsch S, Kühn R, Müller W, Palm N and Rüde E: IL-9 production of naive $\mathrm{CD} 4+\mathrm{T}$ cells depends on IL-2, is synergistically enhanced by a combination of TGF-beta and IL-4, and is inhibited by IFN-gamma. J Immunol 153: 3989, 1994.

9. Schmitt E, Beuscher HU, Huels C, Monteyne P, van Brandwijk R, van Snick J and Ruede E: IL-1 serves as a secondary signal for IL-9 expression. J Immunol 147: 3848-3854, 1991.

10. Angkasekwinai $\mathrm{P}$, Chang $\mathrm{SH}$, Thapa $\mathrm{M}$, Watarai $\mathrm{H}$ and Dong C: Regulation of IL-9 expression by IL-25 signaling. Nat Immunol 11: 250-256, 2010

11. Tamiya T, Ichiyama K, Kotani H, Fukaya T, Sekiya T, Shichita T, Honma K, Yui K, Matsuyama T, Nakao T, et al: $\operatorname{Smad} 2 / 3$ and IRF4 play a cooperative role in IL-9-producing t cell induction. J Immunol 191: 2360-2371, 2013.

12. Ji L, Xu J, Liu J, Amjad A, Zhang K, Liu Q, Zhou L, Xiao J and Li X: Mutant p53 promotes tumor cell malignancy by both positive and negative regulation of the transforming growth factor $\beta$ (TGF- $\beta$ ) pathway. J Biol Chem 290:11729-11740, 2015. 
13. Lu P, Ji X, Wan J and Xu H: Activity of group 2 innate lymphoid cells is associated with chronic inflammation and dysregulated metabolic homoeostasis in type 2 diabetic nephropathy. Scand J Immunol 87: 99-107, 2018.

14. Dardalhon V, Awasthi A, Kwon H, Galileos G, Gao W, Sobel RA, Mitsdoerffer M, Strom TB, Elyaman W, Ho IC, et al: IL-4 inhibits TGF-beta-induced Foxp3+ T cells and, together with TGF-beta, generates IL-9+ IL-10+ Foxp3(-) effector T cells. Nat Immunol 9: 1347-1355, 2008.

15. Stassen M, Schmitt E and Bopp T: From interleukin-9 to T helper 9 cells. Ann N Y Acad Sci 1247: 56-68, 2012.

16. Chang HC, Sehra S, Goswami R, Yao W, Yu Q, Stritesky GL, Jabeen R, McKinley C, Ahyi AN, Han L, et al: The transcription factor PU.1 is required for the development of IL-9-producing $\mathrm{T}$ cells and allergic inflammation. Nat Immunol 11: 527-534, 2010

17. Goswami R and Kaplan MH: Gen 5 Is required for PU.1-dependent IL-9 induction in th9 cells. J Immunol 189: 3026-3033, 2012.

18. Staudt V, Bothur E, Klein M, Lingnau K, Reuter S, Grebe N, Gerlitzki B, Hoffmann M, Ulges A, Taube C, et al: Interferon-regulatory factor 4 is essential for the developmental program of T helper 9 cells. Immunity 33: 192-202, 2010.

19. Goswami R, Jabeen R, Yagi R, Pham D, Zhu J, Goenka S and Kaplan MH: STAT6-Dependent Regulation of Th9 Development. J Immunol 188: 968-975, 2012

20. Liao W, Lin JX and Leonard WJ: IL-2 family cytokines: New insights into the complex roles of IL-2 as a broad regulator of T helper cell differentiation. Curr Opin Immunol 23: 598-604, 2011.

21. Lin PY, Jen HY, Chiang BL, Sheu F and Chuang YH: Interleukin-21 suppresses the differentiation and functions of $\mathrm{T}$ helper 2 cells. Immunology 144: 668-676, 2015.
22. Wong MT, Ye JJ, Alonso MN, Landrigan A, Cheung RK, Engleman E and Utz PJ: Regulation of human Th9 differentiation by type I interferons and IL-21. Immunol Cell Biol 88: 624-631, 2010.

23. Murugaiyan G, Beynon V, Pires Da Cunha A, Joller N and Weiner HL: IFN-gamma limits Th9 mediated autoimmune inflammation through dendritic cell modulation of IL-27. J Immunol 253: 69-69, 2012.

24. Ye J, Wang Y, Wang Z, Ji Q, Huang Y, Zeng T, Hu H, Ye D, Wan J and Lin Y: Circulating Th1, Th2, Th9, Th17, Th22, and treg levels in aortic dissection patients. Mediators Inflamm 2018: 5697149, 2018.

25. Tan C, Wei L, Vistica BP, Shi G, Wawrousek EF and Gery I: Phenotypes of Th lineages generated by the commonly used activation with anti-CD3/CD28 antibodies differ from those generated by the physiological activation with the specific antigen. Cell Mol Immunol 11: 305-313, 2014.

26. Jabeen R and Kaplan MH: The symphony of the ninth: The development and function of Th9 cells. Curr Opin Immunol 24: 303-307, 2012

27. Heldin $\mathrm{CH}$, Landström $\mathrm{M}$ and Moustakas A: Mechanism of TGF-beta signaling to growth arrest, apoptosis, and epithelial-mesenchymal transition. Curr Opin Cell Biol 21: 166-176, 2009.

28. Murillo MM, del Castillo G, Sánchez A,Fernández M and Fabregat I: Involvement of EGF receptor and c-Src in the survival signals induced by TGF-beta1 in hepatocytes. Oncogene 24: 4580-4587, 2005.

29. Takami M, Love RB and Iwashima M: TGF-beta converts apoptotic stimuli into the signal for Th9 differentiation. J Immunol 188: 4369-4375, 2012.

30. Wang A, Pan D, Lee YH, Martinez GJ, Feng XH and Dong C: Cutting Edge: Smad 2 and Smad4 regulate TGF- $\beta$-Mediated Il9 gene expression via EZH2 displacement. J Immunol 191: 4908-4912, 2013. 